\title{
CAGAR BUDAYA MASJID KUNCEN SEBAGAI IKON WISATA SEJARAH DAN RELIGI KOTA MADIUN
}

\author{
Afian Triatmoko \& Anjar Mukti Wibowo*
}

\begin{abstract}
Abstrak
Penelitian ini bertujuan untuk mengetahui sejarah berdirinya dan pelestarian cagar budaya Masjid Kuno Nur Hidayatullah Kelurahan Kuncen Kecamatan Taman Kota Madiun. Melestarikan cagar budaya merupakan bukti kecintaan terhadap nilai-nilai sejarah dan menjadikan cagar budaya tersebut sebagai tempat wisata sejarah bernuansa religi.

Sejarah berdirinya Masjid Kuno Nur Hidayatullah diawali ketika pusat Kabupaten Madiun/Purabaya pindah dari Sogaten ke areal hutan Wonorejo yang sekarang menjadi Kuncen. Bupati saat itu Pangeran Timur atau Penembahan Ronggo Jumeno. Didirikannya Masjid Kuno Nur Hidayatullah digunakan sebagai pengembangan agama Islam di Madiun. Masjid Kuno Nur Hidayatullah potensial sebagai ikon wisata sejarah dan religius. Selain terdapat masjid juga terdapat makam Bupati dan sendang, serta dua prasasti.
\end{abstract}

\section{Kata Kunci: Masjid Kuno, Wisata Sejarah dan Religi}

\section{Pendahuluan}

Kota Madiun merupakan kota yang banyak menyimpan cerita dan catatan sejarah. Nama Madiun dulunya adalah Purabaya, sebuah pusat pemerintahan Kabupaten Madiun sekitar tahun 1575 yang bertempat di Desa Sogaten, Kecamatan Jiwan. Setelah itu pusat pemerintahan dipindah ke areal hutan Wonorejo, sekarang Desa
Kuncen yang merupakan sebuah Desa Perdikan. Perpindahan tersebut disebabkan lalu lintas sungai di Sogaten menjadi dangkal, sulit untuk dilalui kapal layar yang berukuran besar. Pangeran Timur selaku Bupati saat itu memindahkan pusat pemerintahan di Wonorejo. Selain itu sebenarnya banyak aktivitas lain yang pada masa itu memainkan peran penting dalam peristiwa sejarah bangsa Indonesia Afian Triatmoko adalah mahasiswa Program Studi Pendidikan Sejarah IKIP PGRI
Madiun

Anjar Mukti Wibowo adalah Dosen Program Studi Pendidikan Sejarah IKIP PGRI Madiun 
dibuktikan dari banyaknya sisa-sisa aktivitas kehidupan manusia di Kota Madiun, khususnya mengenai bangunan bersejarah (Team,1980: 188-190).

Berbagai macam peninggalan bersejarah terdapat di Kota Madiun, yang di jadikan sebagai cagar budaya guna untuk tetap menjaga dan melestarikannya. Benda cagar budaya merupakan kekayaan budaya bangsa yang penting bagi pemahaman dan pengembangan sejarah serta ilmu pengetahuan dan kebudayaan. Pentingnya dalam pelestarian cagar budaya ini, ditujukan agar terhindarnya dari kerusakan maupun kepunahan. Harapannya bahwa upaya pemeliharaan tersebut dapat dibina dan dikembangkan menjadi objek studi, dan aset budaya nasional serta dapat diwaris teruskan kepada generasi yang akan datang dalam keadaan tetap utuh dan baik.

Urgensi mengkaji sebuah bangunan bersejarah sebagai cagar budaya akan menambah wawasan akan sejarah lokal, termasuk bangunan religius berupa masjid. Kehadiran masjid sebagai media dakwah untuk menyebarkan ajaran Islam dan tempat untuk mencari ilmu agama Islam.

Di Kelurahan Kuncen Ke-

camatan Taman Kota Madiun terdapat sebuah Masjid kuno yaitu Masjid Nur Hidayatullah. Masjid ini banyak dikunjungi oleh warga sekitar Kota Madiun untuk melaksanakan salat malam (tahajud) setiap malam Jumat legi, bertawasul, iktikaf dan lain sebagainya. Masjid Nur Hidayatullah dijadikan sebagai cagar budaya karena keberadaan masjid tersebut dirasakan sebuah masjid kuno yang keberadaannya masih utuh sampai sekarang di Kota Madiun. Masjid Nur Hidayatullah ini memiliki sebuah nilai sejarah tersendiri yang sarat dengan pengembangan ilmu agama Islam. Peninggalan sejarah Masjid Nur Hidayatullah merupakan harta pusaka dari para leluhur yang perlu untuk dilestarikan dan dikembangkan lebih lanjut sebagai kekayaan daerah untuk mencerminkan keluhuran budi pekerti bangsa yang akan mempertebal dan memperkuat kepribadian nasional. Namun yang perlu disayangkan banyak sebagian warga Kota Madiun tidak mengetahui tentang sejarah berdirinya Masjid Nur Hidayatullah, hal ini dapat dilihat dari beberapa warga yang berada disekitaran Masjid Nur Hidayatullah, menganggap bahwa masjid tersebut tidak mempunyai nilai historis yang kuat.

Masjid Nur Hidayatullah ini mempunyai sebuah keunikan tersendiri apabila dibandingkan dengan masjid-masjid lain. Keunikan tersebut dilihat dari segi bangunannya, masjid ini masih terlihat keasliannya apabila Dilihat dari pondasi bangunannya maupun dari tiang penyangga yang terbuat dari kayu jati berjumlah empat.

Masjid Nur Hidayatullah apabila dilihat dari seni bangunanya ada perpaduan antara sebuah candi, dan diihat dari sudut arsitekturnya masjid kuno ini menunjukkan kekhasan yang membedakan dengan masjid di Kota Madiun lainnya. Keunikannya tidak hanya mengenai bangunan arsitektur saja akan tetapi mengenai fungsi dan peran masjid tersebut, yaitu sebagai 
syarat dalam pengembangan ilmu ajaran Islam dengan melakukan sebuah media dakwah, dan juga adanya sebuah tradisi gembrungan atu hadroh sebuah seni musik tradisional Islam berupa alat tabuhan yang akan dimainkan pada waktu Maulud Nabi Muhammad SAW dengan menyanyikan lagu Shalawat, karena Maulud merupakan hari kelahiran Nabi Muhammad SAW. Tradidsi ini dilakukan karena untuk mengenang jasa-jasa beliau dalam penyebaran agama Islam. Masjid Nur Hidayatullah potensial dijadikan sebagai salah satu cagar budaya di Kota Madiun karena memiliki nilai sejarah dan religi.

Bertolak dari uraian di atas peneliti terdorong untuk mengkajinya dengan mengambil judul Kajian Sejarah Masjid Kuno Nur Hidayatullah Sebagai Cagar Budaya Kelurahan Kuncen Kecamatan Taman Kota Madiun.

\section{Tinjauan Pustaka}

Kata masjid secara etimologis tersebut diambil dari akar kata sajada-sujudun, yang berarti patuh, taat, serta tunduk dengan penuh hormat. Meletakkan dahi, kedua tangan , lutut, dan kaki ke tanah yang yang kemudian dinamai sujud oleh syari'at adalah bentuk lahiriyah yang paling nyata dari makna-makna di atas. Dalam pengertian sehari-hari, masjid merupakan bangunan tempat salat bagi kaum muslim. Namun, karena akar katanya mengandung makna tunduk dan patuh, maka hakikat masjid adalah tempat untuk malakukan segala aktivitas yang mengandung kepatuhan kepada Allah semata (Budiman Mustofa,2008:1920).

Menurut R. Soekmono (1975 :75) masjid adalah tempat sujud, yaitu tempat orang bersembah yang menurut peraturan Islam. Sesuai dengan pendirian bahwa Allah itu ada di mana saja, tidak terkait kepada suatu tempat, maka untuk menyembah-Nya manusia dapat melakukan salat di mana-mana. Namun dalam prakteknya untuk melakukan salat itu terutama salat berjamaah orang selalu akan menyediakan tempat tersendiri, tanah lampang yang diberi batas-batas yang nyata atau sebuah bangunan khusus. Bahkan kemudian yang dinamakan Masjid adalah selalu sebuah bangunan.

Nugroho Notosusanto (1984: 287) menegaskan bahwa masjid Adalah tempat peribadatan yang dapat digunakan untuk melakukan salat Jumat. Dan masjid biasanya dibangun dengan ukuran yang sangat besar berbeda sekali dengan langgar yang bangunannya kecil dan tidak bisa digunakan untuk melaksanakan kegiatan salat Jumat.

Berdasarkan beberapa pendapat di atas dapat ditarik kesimpulan Bahwa masjid adalah sebuah bangunan khusus yang diberi batasbatas nyata dan mempunyai fungsi sebagai tempat yang digunakan manusia untuk melaksanakan ibadah salat.

Fungsi dan peran masjid besar seperti pada masa keemasan Islam tentunya sulit untuk diwujudkan pada masa kini. Namun, tidak berarti bahwa masjid tidak dapat berperan di 
dalam kehidupan masyarakat seperti dulu. Khususnya masjid-masjid besar, harus mampu untuk memberikan nasihat dan arahan kepada umat guna mengarahkan mereka pada kehidupan duniawi dan ukhrawi yang lebih baik melelui para pengelolanya. (Budiman Mustofa,2008:30).

Jika kita menengok sejarah Nabi, ada tujuh langkah stategis yang dilakukan oleh Rasul dalam membangun masyarakat Madani di Madinah, yaitu: mendirikan masjid, mengikat persaudaraan antar komu-

nitas muslim, mengikat perjanjian dengan masyarakat non muslim, membangun sistem politik, meletak-

kan sistem dasar ekonomi, membangun keteladanan pada elit masyarakat, dan menjadikan ajaran Islam sebagai sistem nilai dalam masyarakat. Pembangunan masjid yang dilakukan oleh Nabi sebagai langkah pertama adalah dalam rangka membangun masyarakat madani, karena konsep masjid bukan hanya sebagai tempat salat, atau tempat berkumpulnya kelompok masyarakat tertentu, tetapi masjid sebagai majelis untuk memotifisir atau mengendalikan seluruh masyarakat. Pada zaman Rasul, masjid adalah sebagai pusat pengembangan masyarakat dimana setiap hari masyarakat berjumpa dan mendengarkan arahanarahan dari Rasul tentang berbagai prinsip keberagaman, tentang sistem masyarakat baru dan ayat-ayat Qur'an yang baru turun. (Agus Syafii.fungsi masjid.http:///.mail arcif.com/filsafat @yahoogroups.com, diakses 19 Maret 2011).

Pada awalnya peran dan fungsi masjid tidak hanya sebatas mem- fasilitasi pelaksanaan salat saja. Namun, masjid juga berfungsi sebagai pusat pengendalian pemerintah, administrasi, dakwah, sebagai tempat musyawarah, belajar ilmu pengetahuan, sebagai tempat memutuskan perkara, dan sebagai tempat yang berkaitan dengan urusan agama (Budiman Musofa,2008:22). Masjid merupakan sebuah anugrah yang besar, karena menyimpan banyak misteri yang luar biasa. Dengan kehadiran masjid yang berada ditengah-tengah umat dapat membangkitkan kesegaran rohani bagi jiwa setiap umat muslim. Dalam memakmurkan masjid tidak sekedar meramaikan masjid dengan ritualritual salat, namun harus lebih mengarah pada upaya mengerakkan kembali seluruh potensi umat untuk maju dan meraih kemenangan, dengan cara menjalankan fungsifungsi masjid dengan benar.

Pada bentuk awalnya masjid itu bukanlah bangunan yang megah perkasa seperti masjid-masjid yang tampil pada masa kerajaan, yang penuh dengan keindahan dengan ciriciri keagungan arsitektur pada penampilan fisiknya. Masjid pertama yang dibuat oleh Nabi Muhammad SAW adalah sangat sederhana. Denahnya merupakan masjid yang segi empat dengan hanya dindingdinding tersebut dibuat semacam serambi yang langsung bersambungan dengan lapangan terbuka sebagai bagian tengah dari masjid segi empat tersebut. Sedangkan bagian pintu masuknya diberi tanda dengan gapura atau gerbang yang terdiri dari tumpukan batu-batu yang diambil dari sekeliling tempat itu, dan 
juga bahan-bahan yang dipergunakan adalah material apa adanya sekedar yang terdapat di sekeliling tempat itu, sehingga amat sederhana mutu bahan-bahan yang dipergunakan itu, seperti batu-batu alam atau batubatuan gunung, pohon, dahan dan daun kurma (Abdul Rochym,1983: 26).

Dalam perkembangannya masjid di Indonesia mempunyai corak yang khusus antara lain:

1. Atapnya berbentuk tumpang yaitu atapnya yang bersusun, semakin ke atas semakin kecil sedangkan tingkatan Yang paling atas berbentuk limas, atapnya yang bertingkat 3,5. Atap tumpang merupakan bentuk akulturasi dari perkermbangan dua unsur agama Hindu dan Budha yaitu: atap candi yang denahnya bujur sangkar dan selalu bersusun dan puncak stupa paling atas dianggap suci.

2. Denahnya peresegi empat atau bujur sangkar dengan serambi di depan atau di samping, fondasinya pejal dan tinggi pada bagian depan terdapat parit berair.

3. Dengan adanya sebuah menara hal yang menarik, karena pada mulanya masjid tidak ada menaranya, Tempat untuk mengumandangkan adzan atau tempat muaddzin. Meskipun menara itu bukan bagian dari masjid yang harus ada, namun dalam seni bangunan Islam selalu merupakan tambahan yang memberi Keindahan (Nugroho Notosusanto,1984:284).

Di Indonesia hanya pada masjid Kudus dan Banten sajalah yang terdapat adanya sebuah menara. Dan kedua menara tersebut sangat aneh bentuknya: menara Kudus tidaklah lain dari pada sebuah candi Jawa Timur yang telah diubah dan disesuaikan penggunanya yang diberi atap tumpang, sedangkan menara Banten sebaliknya adalah tambahan dari jaman yang kemudian diusahakan oleh seorang pelarian Belanda, Cardeel namanya. Tapi sayangnya bangunan tersebut menyerupai mercu suar Eropa tidak sesuai dengan langgamnya dengan masjid ( R. Soekmono,1975:77).

Dalam arsitektur Islam di Jawa pada hakikatnya tidak terlepas dari keberadaan kebudayaan dan tradisi yang sudah ada sebelum Islam masuk di tanah Jawa. Banyak masjid-masjid yang menggunakan gaya arsitektur tradisional yang cenderung bernuansa Hinduisme, itu tampak pada penggunaan atap tajuk dan pemakaian mustaka pada puncak atapnya. Bahkan pada beberapa masjid ada yang memiliki pendopo di depan masjid atau serambi, karena itu berkaiatan karena masuknya Islam ke Jawa juga berkaiatan dengan kekuasaan raja-raja pada masanya sehingga menghasilkan masjid yang cukup megah dengan kekhasan sendiri.

Ketika Islam masuk di Jawa keberadaan arsitektur Jawa yang telah berkembang dalam konsep dan filosofi jawa tidak dapat dinafikan oleh Islam. Dari seni bangunan pada masjid kuno terdapat empat penyangga tiang di dalam masjid yang terbuat dari kayu, ini memiliki nilai filosofi yaitu bahwa empat tiang itu merupakan filosofi dari empat sahabat nabi yaitu Khulafaur Rasidin, dan juga terdapat tiga atap tumpang 
mempunyai nilai filosofi yaitu memiliki tiga aspek Iman, Islam, dan Ihsan merupakan lambang keislaman.

Sebenarnya semua masjid pada abad ke 18 di Jawa pada prinsipnya mempunyai bentuk yang sama, bahwa tidak ada satu model tunggal masjid kuno sepanjang pesisir utara Jawa, karena pada dasarnya setiap denah ruang salat berbentuk bujur sangkar, sehingga meliputi: terdapatnya mihrab: sebuah tempat kecil pada pusat tembok sebelah barat yang dipakai oleh imam masjid, ruang utama masjid: sebuah ruang yang dipakai untuk salat oleh kaum pria, serambi: beranda sebuah masjid, pawestren: tempat salat bagi jamaah wanita, terdapatnya sebuah kolam: suatu tempat berisi air yang digunakan untuk wudhu, garis axis menuju Mekah: garis maya sebagai orientasi pada pembangunan sebuah masjid, terdapatnya sebuah makam yang berada di belakang masjid, pagar keliling, digunakan sebagai pembatas komplek masjid, gerbang pintu masuk utama di komplek masjid dan makam. Bentuk masjid Jawa pada abad 15 dan 16 , meskipun didirikan pada abad peralihan atau transisi, tetap merupakan ciri khas dan bagian dari sejarah perkembangan arsitektur Jawa. Ciri khas dari arsitektur Jawa terletak pada kemampuannya yang luar biasa untuk membiarkan diri dibanjiri oleh gelombang pengaruh dari luar, dan dalam banjir itu mempertahankan keasliannya. Hinduisme dan Budhisme dirangkul dalam perpaduan unsur kebudayaan dan seni bangunannya masjid yang menyerupai candi. Minaret atau menara tidak dikenal dalam arsitektur masjid kuno Jawa. Sebagai gantinya untuk memanggil jamaah untuk salat, dipergunakanlah bedug. Jadi bedug merupakan cirri khas masjid Jawa kuno, bahwa bedug yang diletakkan di serambi-serambi masjid Jawa merupakan pengaruh dari arsitektur Cina, dimana bedug diletakkan tergantung di serambi kelenteng, tetapi di masjid menara kudus bedugnya diletakkan dibagian atas menara (Handinoto, dalam portofolio.petra.ac.id/user_files/81005/Dimensi1.Pdf, diakses 17 April 2011).

\section{Metode Penelitian}

\section{Tempat dan Waktu Penelitian}

Penelitian ini dilaksanakan di Masjid Kuno Nur Hidayatullah Kelurahan Kuncen, Kecamatan Taman, Kota Madiun. Masjid Kuno Nur Hidayatullah ini merupakan benda cagar budaya yang harus tetap dilestarikan oleh masyarakat Kota Madiun, karena Masjid Kuno Nur Hidayatullah ini merupakan masjid tertua di Kota Madiun. Penelitian ini dilakukan dalam waktu tiga bulan, yaitu di mulai bulan April sampai dengan bulan Juni 2011.

\section{Sumber Data}

Sumber data sangat penting dalam melakukan sebuah penelitian, dengan sumber data ini diupayakan agar dapat membantu dalam memecahkan suatu masalah dan memberikan kemudahan dalam melakukan sebuah penelitian. Untuk itu sumber data yang dipergunakan dalam penelitian ini 
adalah: sumber primer dan sekunder. Sumber data yang bersifat primer antara lain wawancara dan observasi. Sedangkan yang sekunder adalah data kepustakaan maupun dokumendokumen.

3. Pengumpulan Data

Pengumpulan data adalah suatu proses pengadaan data untuk keperluan penelitian. Pengumpulan data merupakan hal yang sangat penting dalam metode ilmiah, karena pada dasarnya semua data yang dikumpulkan dari hasil peneliti itu baik dalam pengertian relevan sepanjang tidak menyimpan dari permasalahan. Pengumpulan data ini menggunakan wawancara, observasi, dan dokumentasi.

4. Analisa Data

Analisa data merupakan pengurutan data sesuai dengan rentan permasalahan atau urutan pemahaman yang ingin diperoleh. Dalam pengorganisasian data dalam formasi, kategori, ataupun unit perian tertentu sesuai dengan antisipasi peneliti.

Mengacu pada model analisis interaktif menurut Miles dan Huberman dalam Maryaeni (1994:431), dalam melakukan kegiatan analisa tersebut peneliti memperhatikan tahap kegiatan interaktif sebagai berikut.

1. Penataan data mentah data tersebut mungkin berupa catatan lapangan rekaman. yang disusun peneliti ketika melakukan kegiatan pengumpulan data.

3. Identifikasi hubungan makna antara data yang satu dengan data yang lain sehingga peneliti dapat menetukan satuan dan hubungan sekuentifnya secara tepat.

\section{Hasil Penelitian}

\section{Sejarah Berdirinya Masjid Kuno Nur Hidayatullah}

Pada tahun 1568 terjadi sejarah baru di Kesultanan Demak yang berdampak di daerah Madiun dan sekitarnya. Setelah berakhirnya perang saudara yang dimenangkan oleh Mas Karebet atau Jaka Tingkir yang selanjutnya disebut Hadiwijaya, dengan restu para wali menggantikan kedudukan mertuanya Sultan Trenggono sebagai sultan, tetapi tidak mau berkedudukan di Demak melainkan memindahkan pusat pemerintahannya ke Pajang. Putra Sultan Trenggono lainnya atau adik ipar Sultan Hadiwijaya yang bernama Pangeran Timur oleh Sunan Bonang yang mewakili para wali diangkat menjadi Bupati Madiun pada tanggal 18 Juli 1568, yang selanjutnya disebut panembahan Rama atau Ki Ageng Panembahan Ronggo Jumeno yang memerintah pada tahun 1568 - 1586.

Pada tahun 1575 dengan berbagai pertimbangan Bupati Pangeran Timur memindahkan pusat pemerintahan dari utara Kelurahan

2. Pemilihan data yang didasar- Sogaten ke selatan menuju Keluran kan pada hasil penulisan ulang, transkripsi maupun catatan reflektif dan memo

Kuncen dulu Wonorejo. Pangeran Timur selaku Bupati disamping berkewajiban mengendalikan jalan- 
nya pemerintahan, juga membawa Kuncen tersebut dahulu dikenal misi penyebaran agama Islam. dengan nama Masjid Kuno Kuncen, Pembangunan agama identik atau kerana keberadaan masjid tersebut tidak lepas dengan pembangunan berdekatan dengan makam yang tempat ibadah yaitu masjid. Dengan demikian patut diduga bahwa masjid Kuno Kuncen atau disebut Masjid Nur Hidayatullah pada zaman Bupati Pangeran Timur memerintah Kabupaten Madiun yang berpusat di sekitar Kelurahan Kuncen dan masjid tersebut berdiri di Kuncen setelah tahun 1575 atau pada akhir abad XVI. Status wilayah Wonorejo sebagai tanah makam dan juga ada masjid, maka Kyai yang merawat areal tersebut juga bertindak sebagai kepala desa, dan diberi kebebasan menguasai daerah sekitar area makam dan masjid. Kyai Grubug merupakan guru dalam ilmu agama Islam, dan Kyai Grubug inilah yang pertama kali berkuasa di Desa Perdikan Kuncen ini yang juga terdapat juru kunci kemudian dinamakan Kuncen dan juga disesuaikan dengan nama Kelurahan Kuncen karena keberadaan masjid berada di Kelurahan Kuncen, maka dari itu masjid kuno ini dikenal dengan nama Masjid Kuno Kuncen. Selanjutnya pada tahun 1970 warga Kuncen bersepakat merubah nama Masjid sebelumnya Masjid Kuno Kuncen diubah nama menjadi Masjid Nur Hidayatullah, walaupun sudah dinamakan Masjid Nur Hidayatullah akan tetapi nama yang masih dikenal oleh warga Madiun sampai sekarang adalah Masjid Kuno Kuncen.

\section{Pelestarian Cagar Budaya Masjid Kuno Nur Hidayatullah}

Berdasarkan hasil studi kelayamengelola masjid maupun makam, kan yang dilakukan oleh Departemen hingga sekarang ada empat belas Kyai yang pernah berkuasa di Desa perdikan Kuncen beserta mengurusi masjid dan makam, diantaranya: 1).Kyai Grubug, 2).Kyai Semin I, 3).Kyai Semin II, 4).Kyai Semin III, 5).Kyai Semin IV, 6). Kyai Djodo, 7).Kyai Muhammad Ngarib, 8).Kyai Kasan Basari, 9).Kyai Muhammad Mardo, 10).Kyai Muhammad Mardi, 11).Kyai Darsono, 12).Kyai Sutopo, 13).Kyai Karsono, 14).Kyai Kentjono.

Sebenarnya masjid yang ada di Kelurahan Kuncen itu belum ada nama sama sekali, karena tidak adanya sumber tertulis mengenai nama masjid tersebut. Selanjuutnya dari tahun ke tahun nama masjid kuno yang terdapat di Kelurahan Pendidikan dan Kebudayaan Republik Indonesia Kantor Wilayah Propinsi Jawa Timur, Bagian Proyek Wilayah Propinsi Jawa Timur, Bagian Proyek Pembinaan Peninggalan Sejarah dan Kepurbakalaan (P2SK) Jawa Timur, terhadap Masjid Kuno Nur Hidayatullah Kelurahan Kuncen, Kecamatan Taman, Kota Madiun merupakan masjid tertua di Madiun yang merupakan suaka purbakala. Masjid Nur Hidayatullah sebagi cagar budaya ditetapkan pada tanggal 29 Juni 2010 oleh Walikota Madiun H. Bambang Irianto.

Pada 17 April 2009 diadakan pemugaran pada Masjid Nur Hidayatullah. Adapun bagian-bagian yang dipugar melipui: pembangunan 
pendopo, pembangunan gapura, pembangunan tempat wudhu, dan penataan halaman, lantai masjid dinaikan +0.40 , tinggi tembok masjid +3.50 , lantai marmer, reng lama $2 / 3$ diganti baru $3 / 5$, rangka kayu lama diekspos / dihaluskan, rangka kayu lapuk diganti baru, pasang plapon klasibord, pengecatan tembok, plapon dan pelituran rangka kayu. Pembangunan tersebut tidak mengurangi keaslian arkeologis masjid tersebut (wawancara Soedjono, 15 Mei 2011).

Pelestarian cagar budaya masjid kuno ini melibatkan warga sekitar maupun pengurus masjid sekitar mengadakan bersih-bersih masjid setiap hari pada jam enam pagi dan jam setengah lima sore hari, secara rutin agar usaha ini dapat memperindah dan tidak merusak cagar budaya masjid kuno tersebut, karena cagar budaya tersebut merupakan harta pusaka yang berharga dari nenk moyang.

Selain itu dalam rangka pelestarian Masjid Kuno Nur Hidayatullah juga diadakan latihan Hadroh. Kesenian ini merupakan kesenian asli tradisional umat Islam yang menyanyikan lagu sholawat nabi Muhammad SAW. Di samping itu juga acara pengajian untuk menambah wawasan mengenai ajaran agama Islam agar keberadaan masjid tersebut tidak sepenuhnya untuk ibadah salat saja (wawancara Bayu Warsito, 15 Mei 2011).

Pemerintahan Kota Madiun mengembangkan cagar budaya di Kelurahan Kuncen ini sebagai wisata sejarah dan religi. Di samping masjid juga terdapat Makam Bupati I Madiun Pangeran Timor dan sebuah Sendang
Tundhung Medion. Wisata sejarah dan religi ini akan menambah aset budaya bagi Kota Madiun, dan juga berguna bagi wilayah sekitar untuk mengembangkan usaha-usahanya (wawancara Basari, 26 April 2011).

Pengembangan pelestarian cagar budaya bernuansa religi, maka di selatan Masjid Nur Hidayatullah akan dibangun sebuah pondok pesantren sebagai pengembangan kegiatan yang menunjang kemakmuran masjid sekaligus untuk menyiapkan generasi penerus yang berkualitas, menghafal, memahami dan berakhlak Al -Qur'an. Tanah yang akan dibangun sebuah pondok pesantren merupakan tanah wakaf kolektif dengan cara membeli sebidang tanah tersebut seluas \pm 665 $\mathrm{m} 2$, nama pondok tersebut adalah Pondok Pesantren Tahfidzul - Qur'an (wawancara Soedjono, 15 Mei 2011).

Pelestariann cagar budaya ini dengan kegiatan pembangunan sampai sekarang masih dilakukan secara bertahap dan terpadu dalam suatu koordinasi secara aktif dan selektif sejak awal dari perencanaan hingga tindak pelaksanaannya. Kesemuanya ini dituntut dan tanggung jawab yang tinggi serta rasa pengabdian yang tulus ikhlas demi kepentingan bersama, masyarakat sekitar maupun generasi peneruslah yang merupakan faktor penentu secara langsung dalam pelestarian cagar budaya demi kelangsungan hidup kebudayaan nasional. Masjid Kuno Nur Hidayatullah merupakan sebuah masjid suaka purbakala yang memiliki nilai historis dan arkeologis serta religi yang sangat tinggi dan bernilai. 
Nilai- nilai tersebut adalah kecintaan terhadap agama Islam, rasa solidaritas antar warga masyarakat, dan rasa kerukunan antar umat beragama, serta nilai arkeologinya yang terkandung dalam cagar budaya ini merupakan pada seni bangunan masjid yang merupakan ada perpaduan akulturasi antara agama Hindu, Budha dan juga terhadap pertukangan Cina yang dibuktikan dengan atap tumpang dan diserambi depan terdapat bedug untuk bertnda adzan berkumandang.

\section{Pembahasan}

Pada tahun 1568 terjadilah sejarah baru di Kesultanan Demak yang berdampak di daerah Madiun dan sekitarnya. Setelah berakhirnya perang saudara yang dimenangkan oleh Mas Karebet atau Jaka Tingkir yang selanjutnya disebut Hadiwijaya, dengan restu para wali menggantikan kedudukan mertuanya Sultan Trenggono sebagai sultan, tetapi tidak mau berkedudukan di Demak melainkan memindahkan pusat pemerintahannya ke Pajang. Putra Sultan Trenggono lainnya atau adik ipar Sultan Hadiwijaya yang bernama Pangeran Timur oleh Sunan Bonang yang mewakili para wali diangkat menjadi Bupati Madiun pada tanggal 18 Juli 1568, yang selanjutnya disebut panembahan Rama atau Ki Ageng Panembahan Ronggo Jumeno yang memerintah pada tahun 1568 - 1586.

Pada tahun 1575 dengan berbagai pertimbangan Bupati Pangeran Timur memindahkan pusat pemerintahan dari utara Kelurahan
Sogaten ke selatan menuju Keluran Kuncen dulu Wonorejo. Pangeran Timur selaku Bupati disamping berkewajiban mengendalikan jalannya pemerintahan, juga membawa misi penyebaran agama Islam. Pembangunan agama identik atau tidak lepas dengan pembangunan tempat ibadah yaitu masjid. Dengan demikian patut diduga bahwa masjid Kuno Kuncen atau disebut Masjid Nur Hidayatullah pada zaman Bupati Pangeran Timur memerintah Kabupaten Madiun yang berpusat di sekitar Kelurahan Kuncen dan masjid tersebut berdiri di Kuncen setelah tahun 1575 atau pada akhir abad XVI.

Dalam pelestarian cagar budaya yang terdapat di Kelurahan Kuncen, sebagian masyarakat Kuncen turut serta dalam pelestarian cagar budaya dengan melakukan sebuah aktivitas dengan memakmurkan masjid yang diisi dengan kegiatan-kegiatan religius seperti mengadakan salat malam setiap malam jumat legi dengan berjamaah, mengadakan seni latihan hadroh, TPA, pengajian rutin setiap hari minggu pagi. Dalam merawat bangunan cagar budaya masyarakat Kuncen juga melakukan sebuah perawatan dengan melakukan sebuah aktivitas setiap hari yaitu dengan melakukan bersih-bersih sekitar areal masjid setiap pagi dan sore, ini bertujuan untuk menjaga kenbersihan terhadapa masjid karena Kebersihan merupakan bagian dari Iman.

Pemugaran cagar budaya sudah Teralaksana dengan baik dalam Pemugaran masjid ini merupakan dana dari Pemerintahan Kota Madiun serta warga sekitar Kelurahan Kun- 
cen. Dalam pemugaran ini tidak merubah sedikitpun dari keaslian nilai arkelogisnya, pemugaran ini dilakukan untuk memperindah bangunan dan juga untuk merawat terhadap bangunan yang sudah tua.

Dalam pengembangan pelestarian cagar budaya bernuansa religi, maka di selatan Masjid Nur Hidayatullah akandibangun sebuah pondok pesantren. Berguna sebagai pengembangan kegiatan yang menunjang kemakmuran masjid, sekaligus untuk menyiapkan generasi penerus yang berkualitas, menghafal, memahami dan berakhlak Al-Qur'an, tanah yang akan dibangun sebuah pondok pesantren merupakan tanah wakaf kolektif dengan cara membeli sebidang tanah tersebut seluas \pm 665 $\mathrm{m} 2$, nama pondok tersebut adalah Pondok Pesantren Tahfidzul - Qur'an. Dana untuk mendirikan sebuah Pondok Pesantren ini merupakan iuran sukarelawan dari berbagai pihak warga Kelurahan Kuncen. Pendirian Pondok Pesanten ini juga merupakan sebuah alat untuk melestarikan sebuah cagar budaya karena diisi dengan aktivitas-aktivitas religius, karena dalam melestarikan atau memakmurkan masjid tidak hanya dalam kegiatan salat saja akan tetapi harus diisi dengan kegiatankegiatan yang dapat menambah wawasan pengetahuan serta nilainilai agama.

Perlindungan terhadap benda cagar budaya merupakan kegiatan yang memerlukan adanya berbagai bentuk koordinasi antar berbagai pihak dan perlindungan berarti menjaga kelestariannya,dalam situasisituasi tertentu kita memang dihadap- kan pada suatu dilema apabila tuntutan perlindungan warisan sejarah dan budaya itu berhadap-hadapan dengan kepentingan ekonomi (Edi Sedyawati, 2006:83).

Dalam pelestarian cagar budaya , tidak hanya dengan membersihkan secara rutin terus menerus akan tetapi dengan melakukan dengan Mengadakan pemugaran terhadap bangunan yang sudah rusak yang sewaktu-waktu bisa memabahayakan, dan tidak sedap apabila dilihat. Selanjutnya dalam pelestarian cagar budaya ini juga bisa digunakan untuk media pembelajaran dimana dalam cagar budaya memiliki sebuah nilai nilai sejarah yang dapat memotivasi peserta didik akan memperoleh banyak ilmu pengetahuan.

Dalam pelestarian cagar budaya juga dapat memakai berbagai aspek mengenai nilai-nilai sosial yang menunjang dikalangan masyarakat seperti mensosialisasikan kepada seluruh warga Madiun sekitarnya maupun kota lain bahwa di Kelurahan Kuncen terdapat masjid kuno yang bersejarah, dengan membuat pamphlet-pamflet maupun disosialisasikan lewat jejaring sosial. Sedangkan dengan nilai-nilai religius menitik beratkan pada memakmurkan masjid dengan mengisi kegiatan-kegiatan yang menunjang seperti pengajian, baca Al-qur'an dan lain sebagainya. Masjid Nur Hidayatullah adalah Merupakan harta pusaka nenek moyang yang harus tetap dijaga kelestariannya, karena bangunan religi berupa masjid merupakan sebuah akulturasi budaya yang telah menyebarkan agama Islam dengan media membangun sarana prasarana 
sebagai tempat ibadah. Dalam menjaga kelestarian dan pemanfaatan benda cagar budaya berupa bangunan dapat digunakan untuk memupukkan jiwa akan kecintaan terhadap hasil budaya, sehingga juga baik untuk pendidikan maupun untuk pariwisata guna menambah pendapatan pemerintah Kota Madiun.

\section{Simpulan}

Sejarah berdirinya Masjid Kuno Nur Hidayatullah diawali padawaktu kerajaan Purabaya pindah ke hutan Wonorejo yang sekarang Kelurahan Kuncen, dipimpin oleh seorang Bupati I Madiun bernama Pangeran Timur (Panembahan Ronggo Jumeno). Berdirinya Masjid Kuno Nur Hidayatullah sebagai saranan dalam penyebaran agama Islam. Pendiri Masjid Nur Hidayatullah adalah Bupati I Madiun yang bernama Panembahan Ronggo Jumeno, berdirinya masjid ini diperkirakan pada akhir abad XVI.

Cara pelestarian cagar budaya berupa bangunan religi dengan melakukan pemugaran pada bagian bangunan yang rusak karena umur bangunan yang sudah tua, pemugaran tetaplah sebagai upaya melestarikan dan melindungi benda cagar budaya. Adapun bagian - bagian yang dipugar pada Masjid Nur Hidayatullah, meliputi: pembangunan pendopo, pembangunan gapura, pembangunan tempat wudhu, penataan halaman, lantai masjid dinaikan $+0,40$ tinggi tembok masjid +3.50 , lantai marmer, reng lama diganti baru 3/5, rangka kayu lama diekspos / dihaluskan, rangka kayu lapuk diganti baru. Pembangunan tersebut tidak mengurangi keaslian arkeologi masjid tersebut.

\section{Saran}

\section{Bagi Pemerintah}

Dengan adanya cagar budaya berupa bangunan religi ini diharapkan kepada pemerintah pusat khusunya Pemerintahan Kota Madiun, menjadikan cagar budaya yang terdapat di Kelurahan Kuncen berupa masjid, makam dan sendang dapat dijadikan sebagai tempat pariwisata bernuansa religi, karena ini merupakakan aset Pemerintahan Kota Madiun yang sangat menunjang bagi kehidupan bersama khususnya warga sekitar Kuncen maupun warga Kota Madiun.

2. Bagi Masyarakat Dan Pengurus Masjid

Bagi masyarakat dan pengurus masjid sekitar Kelurahan Kuncen diharapkan untuk senantiasa untuk tetap menjaga dan melestarikan cagar budaya yang ada di Kelurahan Kuncen berupa masjid, makam, dan sendang agar tidak punah dan rusak keberadaannya, karena cagar budaya merupakan harta pusaka dari nenek moyang yang harus dijaga dan dilestarikan.

\section{Bagi Dinas Pariwisata Dan} Kebudayaan

Bagi pihak Dinas Pariwisata dan Kebudayaan seharusnya mengambil langkah cepat untuk menjadikan cagar budaya yang terdapat di Kelurahan Kuncen tersebut di jadikan sebagai obyek wisata religius, agar 
terhindar dari kepunahan dan tetap terjaga kelestariannya.

4. Bagi IKIP PGRI Madiun

Sebagai bahan refrensi buku bagi perpustakaan maupun laboratorium sejarah, guna menambah wawasan ilmu pengetahuan dan turut serta dalam pelestarian cagar budaya. 


\section{Daftar Pustaka}

Abdul Rochym. 1983. Sejarah Arsitektur Islam. Bandung: Angkasa.

Aminudin Kasidi. 2003. Memahami Sejarah. Surabaya: Unesa University Press.

Agus Syafii. Fungsi Masjid. http: ///. Mail

arcif.com/filsafat@yahoogro

ups.com, diakses 19 Maret 2011.

Basari. 2006. Metode Penelitian Sejarah. Jakarta: Restu Agung.

Basrowi dkk. 2008. Memahami Penelitian Kualitatif. Jakarta: Rineka Cipta.

Budiman Mustofa. 2008. Manajemen Masjid. Surakarta: Ziyad Visi Media.

Burhan Bungin. 2007. Penelitian Kualitatif. Jakarta: Kencana Pranada Media Group.

Bibit Sri Utami.2005.Sejarah Masjid Besar Kuno Donopura Kelurahan Kuncen Kecamatan Taman Kota Madiun Tahun 1725 2003.Madiun:Program Pasca Sarjana IKIP PGRI Madiun.

Cholid Narbuko dkk. 2003. Metode Penellitian. Jakarta: Bumi Aksara.

Direktorat Peninggalan Purbakala. Benda Cagar Budaya dan Situs.

http://www.pemeliharaan.c o.id diakses 12 Maret 2011.
Seni, dan Sejarah. Jakarta: PT Rajagrafindo Persada.

Handinoto. Pengaruh Pertukangan Cina Pada Bangunan Masjid Kuno Di Jawa.http://portofolio.petra. ac.id/user_files/81005/Dimensi.Pdf, diakses 17 April 2011.

Herybertus Sutopo, 2006. Metodologi

Penelitian Kualitatif.

Surakarta: Universitas

Sebelas Maret.

Husaini Usman. 2004. Metodologi Penelitian Sosial. Jakarta: PT Bumi Aksara.

Joko Subgyo. 2004. Metode Penelitian

Dalam Teori dan Praktek.

Jakarta: Rineka Cipta.

Maryaeni. 2005. Metode Penelitian Kebudayaan. Jakarta: Sinar Grafika Offset.

Nasution, M.A.2004.Metode Research.Jakarta: PT. Bumi Aksara .

Nugroho Notosusanto. 1984. Sejarah Nasional Indonesia IIl. Jakarta: PN Balai Pustaka.

Nyoman Kutha Ratna. Metode Penelitian Kajian Budaya Sosial Humaniora Pada Umumnya. Yogyakarta: Pustaka Pelajar.

Pemerintahan Kabupaten Daerah Tingkat II Madiun. 1980. Sejarah Kabupaten Madiun.

Pemerintahan Kota Madiun.2007. Sejarah Kelurahan Kuncen.

R. Soekmono. 1975. Pengantar Sejarah Kebudayaan Indonesia 3. Yogyakarta: Kanisius.

Edy Sedyawati. 2007. Budaya Tim Penyusun Ensiklopedia Nasional Indonesia Kajian Arkeologi Indonesia. 
Ensiklopedia Nasional

Indonesia. Jakarta: PT Cipta

Adi Pustaka.

Tim Penyusun UUD 1945. Undang Undang Republik Indonesia

Tentang Benda Cagar

Budaya.

http://www.kbn.co.id/web2

009/upload/pdf/peraturan

Indonesia/UU/UU No.5

1992, diakses 12 Maret

2011. 